\title{
Wyjazd naukowy studentów Wydziału Prawa Kanonicznego UPJPII do Rzymu (14-21 maja 2017)
}

\author{
DOI: http://dx.doi.org/10.15633/acan.2231
}

Podtrzymując coroczną tradycję obowiązującą na Wydziale Prawa Kanonicznego Uniwersytetu Papieskiego Jana Pawła II w Krakowie, studenci trzeciego roku studiów licencjackich wraz z opiekunem ks. dr. Andrzejem Sosnowskim, prodziekanem WPK, oraz ks. dr. Bartłomiejem Pieronem uczestniczyli w dniach od 14 do 21 maja 2017 roku w wyjeździe naukowym do Rzymu. Jego nadrzędnym celem było uzupełnienie przez studentów swojej wiedzy teoretycznej, zdobytej podczas studiów prawa kanonicznego, o doświadczenie praktyczne, pozwalające przede wszystkim na zapoznanie się z faktycznym funkcjonowaniem trybunałów papieskich, a także niektórych kongregacji. Ułożony już wcześniej harmonogram wyjazdu przewidywał także wizytę w Ambasadzie Rzeczypospolitej Polskiej przy Stolicy Apostolskiej oraz na Papieskim Uniwersytecie Gregoriańskim.

Pierwsze z zaplanowanych spotkań odbyło się 15 maja w Ambasadzie Rzeczypospolitej Polskiej przy Stolicy Apostolskiej mieszczącej się przy Via dei Delfini. Punktualnie o godzinie 9.30 na studentów oczekiwał Janusz Kotański - ambasador nadzwyczajny i pełnomocny Rzeczypospolitej Polskiej przy Stolicy Apostolskiej i Zakonie Kawalerów Maltańskich. Wszyscy zgromadzeni mieli okazję wysłuchać, jak funkcjonuje placówka ambasady oraz jakie obowiązki i zadania spoczywają na osobie ambasadora. Ambasador przedstawił po krótce, jak wygląda jego codzienny harmonogram pracy, z jakimi osobami się spotyka oraz jak wygląda współpraca ze Stolicą Apostolską. Po audiencji wszyscy uczestniczący w spotkaniu, w towarzystwie Pana Ambasadora, mogli swobodnie przyjrzeć się wnętrzom budynku, w szczególności pięknym obrazom, a także mogli podziwiać Rzym z tarasu przynależącego do budynku ambasady.

Tego samego dnia, w godzinach południowych, odbyła się kolejna wizyta studentów, tym razem w siedzibie Penitencjarii Apostolskiej przy Piazza della Cancelleria. W tej najstarszej Dykasterii Kurii Rzymskiej zebraną grupę przywitał ksiądz prałat dr Krzysztof Nykiel - regens Penitencjarii Apostolskiej. W słowie wprowadzającym wspomniał, że przedstawiana dykasteria, to tak naprawdę Trybunał Miłosierdzia, który służy Kościołowi w sposób szczególny, dając możliwość pojednania się z Bogiem, bowiem penitent to osoba znajdująca się w potrzebie, która ma zranioną duszę i potrzebuje lekarstwa, a jest nim Boże Miłosierdzie. W związku z powyższym prerogatywą pracy Penitencjarii Apostolskiej stała się 
szybkość działania - przedstawiane sprawy rozpatrywane są, co do zasady, w ciągu dwudziestu czterech godzin od momentu wpłynięcia do trybunału, bo - jak nadmienił ksiądz prałat Nykiel - przymiot Bożego Miłosierdzia charakteryzuje się tym, że na miłosierdzie nie można długo czekać. Codzienne z całego świata przysyłane są do rozpatrzenia kazusy dotyczące różnych sytuacji penitentów, które kierowane są do Penitencjarii Apostolskiej przez spowiedników. To właśnie spowiednicy mają już pewien osąd sytuacji i znają penitenta, dlatego też potrafią dobrze przedstawić sytuację, w jakiej się znalazł.

W dalszej części spotkania o. Robert scharakteryzował Penitencjarię Apostolską w oparciu o jej trzy główne obszary działania, tj.: przestępstwa zastrzeżone Stolicy Apostolskiej na forum wewnętrznym, odpusty na forum zewnętrznym oraz kompetencje w zakresie sprawowania sakramentu pojednania (pytania od spowiedników). Po wygłoszonym wykładzie o. Robert oprowadził studentów po wnętrzach penitencjarii, na końcu zaprowadził nas do pięknego archiwum trybunału, w którym znajdują się dokumenty sięgające nawet XV wieku.

Kolejnego dnia w godzinach porannych odbyła się wizyta w Najwyższym Trybunale Sygnatury Apostolskiej, który sąsiaduje z uprzednio zwiedzaną Penitencjarią Apostolską. Liczną grupę studentów, na czele z ks. dr. Andrzejem Sosnowskim, powitał serdecznie ksiądz prałat dr Paweł Malecha, substytut promotora sprawiedliwości. W pierwszej kolejności opisał obecny skład personalny NTSA i krótko scharakteryzował każde stanowisko. Wskazał również na szczególny sposób zatrudniania pracowników kancelarii. Mianowicie, kandydaci do pracy wybierani są z różnych stron świata, ponieważ istotną umiejętnością przydatną w Sygnaturze Apostolskiej jest znajomość języków obcych. Ogólnie obowiązującą zasadą jest, że pisma wewnętrzne oraz wszystkie wyroki wydane przez NTSA pisane są po łacinie. Zasadniczo odpowiedzi powinny być również pisane w języku łacińskim, jednak osobom fizycznym odpowiada się w ich językach narodowych, o ile jest to faktycznie możliwe. I w tym zakresie ogromne znaczenie ma znajomość języków obcych, którą wykazują się osoby zatrudnione w kancelarii NTSA.

Następnie ks. Paweł Malecha omówił kompetencje NTSA w oparciu o ich podział na trzy sekcje, jednak tylko w ogólnym zakresie, a to dlatego, że studenci obecni na spotkaniu uczestniczyli w wykładach gościnnych, jakie ksiądz prałat miał okazję wygłosić na Wydziale Prawa Kanonicznego UPJPII w ubiegłym roku akademickim i które dotyczyły właśnie tej materii.

Drugie spotkanie, zaplanowane na ten dzień, miało miejsce w Trybunale Roty Rzymskiej, gdzie na studentów oczekiwał ksiądz prałat prof. Grzegorz Erlebach. 
Goście mieli okazję wysłuchać wykładu na temat historii kształtowania się tego Trybunału Apostolskiego. Między innymi zostało wspomniane, że po soborze trydenckim Rota Rzymska zajmowała się tylko sprawami spornymi, natomiast sprawy natury duchowej, a także sprawy o stwierdzenie nieważności małżeństwa były rozstrzygane przez poszczególne kongregacje. Dopiero po dużej reformie Kurii Rzymskiej dokonanej przez Papieża Piusa x Trybunał Roty Rzymskiej był właściwy do rozpatrzenia spraw o stwierdzenie nieważności małżeństwa.

Funkcjonowanie Roty Rzymskiej jest oparte na normach rotalnych. Ksiądz prałat wyjaśnił również, dlaczego sprawa w rocie trwa długo - przede wszystkim dlatego, że Rota Rzymska nie komunikuje się ze stronami bezpośrednio (taka forma jest możliwa tylko dla stron pochodzących z Włoch), lecz robi to poprzez trybunały lokalne, które świadczą pomoc prawną. Strona powodowa musi mieć własnego adwokata, a jeżeli go nie posiada, to jest możliwość otrzymania adwokata z urzędu. W skład Trybunału Roty Rzymskiej wchodzą sędziowie, którzy tworzą kolegium na czele z dziekanem Roty Rzymskiej, promotor sprawiedliwości oraz promotor sprawiedliwości dla Kościołów wschodnich. Na czele kancelarii stoi kanclerz, a w jej skład wchodzi dwóch notariuszy, pierwszy z nich komunikuje się ze światem zewnętrznym, prowadzi najważniejsze rejestry wyroków, dekretów, repertoriów, natomiast drugi notariusz wykonuje dekrety zarządzające sędziów. W ciągu roku Trybunał Roty Rzymskiej prowadzi około 400 spraw zasadniczych. Wszystkie sprawy, pisma, a także dekrety zarządzające pisane są po łacinie. Jedynie w sprawach spornych, które się zdarzają, pozwala się, żeby dyskusja odbywała się w językach narodowych, ale wyrok pisany jest również w języku łacińskim. Jeżeli wpłyną sprawy w językach oficjalnych, tzn. włoskim, łacińskim, angielskim, hiszpańskim, francuskim czy portugalskim, to takich spraw się nie tłumaczy, bowiem wszyscy sędziowie są zobowiązani, żeby przynajmniej rozumieć te języki i swobodniew nich czytać. Dodał tė̇, że mimo iż język niemiecki nie jest uznawany jako język oficjalny, to ponieważ zna go wystarczająco dużo osób, normy pozwalają na to, aby wyznaczyć turnus, który bez tłumaczenia poprowadzi sprawy także w tym języku.

Spraw pochodzących z Polski jest również bardzo dużo - co do ilości zajmują one trzecie miejsce spośród wszystkich. Zasadą jest, że sprawy w naszym ojczystym języku muszą zostać przetłumaczone, jednak gdy dziekan Roty wyznaczy turnus, który posługuje się językiem polskim, to zasada co do tłumaczenia nie obowiązuje.

Na koniec wizyty w Trybunale Roty Rzymskiej studenci mieli okazję uczestniczyć w modlitwie pod przewodnictwem dziekana Roty ks. prałata Pio Vito Pinto, który później zaprosił ich na krótki wykład. 
17 maja 2017 roku w godzinach porannych studenci mieli okazję uczestniczyć w audiencji generalnej ojca świętego Franciszka, która odbyła się na placu Świętego Piotra w Watykanie. To wydarzenie budzi ogromne zainteresowanie wiernych, co można było stwierdzić po bardzo dużej liczbie zebranych pielgrzymów, przybywających, by uczestniczyć w katechezie papieża. Wśród zgromadzonych sporą grupę stanowili pielgrzymi z Polski, którzy mogli usłyszeć czytane słowo Boże w języku ojczystym.

Drugie z zaplanowanych spotkań na ten dzień odbyło się w Papieskiej Radzie ds. Tekstów Prawnych, znajdującej się przy Piazza Pio xı I w Watykanie. Spotkanie poprowadził przewodniczący Rady Je kard. Francesco Coccopalmerio. Na wstępie spotkania przedstawiony został zakres głównych kompetencji, jakie posiada Rada ds. Tekstów Prawnych, a do których należą między innymi: legislacja, interpretacja autentyczna przepisów dotyczących zarówno Kościoła łacińskiego, jak i Kościołów wschodnich, kierowanie propozycji uregulowania prawnego tzw. „luk prawnych” w przepisach tych Kościołów, kontrola stosowania przepisów prawnych - czuwanie nad właściwym ich przestrzeganiem, a także działania z szeroko pojętym rozwojem i promowaniem prawa kanonicznego.

Papieska Rada ds. Tekstów Prawnych jest zobowiązana odpowiadać na skierowane do niej pisma zawierające pytania czy też wątpliwości interpretacyjne dotyczące przepisów prawnych. W związku z tym podkreślono, że w obszarze działania diecezji istnieje potrzeba zatrudniania przynajmniej jednego kanonisty, który pomógłby rozwiązać niektóre choćby niejasności interpretacyjne pojawiające się w konkretnych zdarzeniach faktycznych.

Kolejnego dnia, z samego rana, studenci uczestniczyli we mszy świętej odprawianej przy grobie św. Jana Pawła II w bazylice Świętego Piotra w Watykanie. Mszy świętej przewodniczył ks. abp Stanisław Gądecki, metropolita poznański oraz przewodniczący Konferencji Episkopatu Polski. Była to szczególna uroczystość, ponieważ w tym dniu przypadała 97. rocznica urodzin św. Jana Pawła II.

Następnie studenci skorzystali z zaproszenia do zwiedzania Papieskiego Uniwersytetu Gregoriańskiego, potocznie nazywanego „Gregorianą”, założonego przez św. Ignacego Loyolę w 1551 roku. Historię i funkcjonowanie tego najstarszego uniwersytetu papieskiego przedstawił słuchaczom o. prof. Janusz Kowal. Podkreślone zostało ogromne znaczenie uczelni dla Kościoła katolickiego, ponieważ daje ona możliwość zdobywania wiedzy i praktyki ludziom z całego świata. Zebrani studenci mieli okazję zobaczyć sale wykładowe oraz seminaryjne, a także bibliotekę uniwersytecką. 
Ostatnim z oficjalnie zaplanowanych spotkań podczas pobytu w Rzymie była wizyta w Kongregacji Spraw Kanonizacyjnych, mającej siedzibę przy Piazza Pio XII, na której czele stoi kard. Angelo Amato. Spotkaniu przewodniczył podsekretarz Kongregacji ksiądz prałat dr Bogusław Turek. Studenci mieli już okazję poznać księdza prałata podczas wykładów gościnnych odbywających się dokładnie tydzień wcześniej na Uniwersytecie Papieskim Jana Pawła II, dlatego też ks. Turek gwoli przypomnienia wspomniał o historii i zadaniach Kongregacji Spraw Kanonizacyjnych, a następnie zaprosił studentów do zwiedzania przynależnych jej pomieszczeń, zatrzymując się najdłużej w archiwum Kongregacji, w którym znajdują się dokumenty datowane od 1588 roku do dnia dzisiejszego.

Niedziela 21 maja była ostatnim dniem pobytu studentów Wydziału Prawa Kanonicznego Uniwersytetu Papieskiego Jana Pawła II w Rzymie. Na zakończenie wspólnego wyjazdu naukowego wszyscy zebrali się w kościele św. Alfonsa na Eskwilinie, będącym jednocześnie Sanktuarium Matki Bożej Nieustającej Pomocy, aby uczestniczyć we mszy świętej.

Wyjazd do Rymu był dla studentów kolejnym ciekawym wydarzeniem, jakiego mogli doświadczyć w czasie studiów. Praktyczne poznanie funkcjonowania trybunałów papieskich, a także niektórych kongregacji przyczyniło się do nowego spojrzenia na te instytucje. Zawsze doznania empiryczne pozwalają na pełniejsze zrozumienie tematu, a dzięki temu studenci mogli się przekonać, że to, co było przedmiotem ich nauki przez ostatnie lata, stanowi podstawę funkcjonowania czołowych instytucji w hierarchii Kościoła. Wspólny wyjazd okazał się nie tylko doświadczeniem naukowym, ale i doskonałym pretekstem do spędzania razem czasu, wspólnych rozmów, wspólnego zwiedzania, jak również zaowocował przyjaźniami na długi czas.

Tym samym szczególne podziękowania składamy księdzu dziekanowi prof. dr. hab. Tomaszowi Rozkrutowi za organizację spotkań w poszczególnych instytucjach oraz zaufanie i wsparcie, jakimi nas obdarzył przez trzy lata studiowania na Wydziale Prawa Kanonicznego, a także księdzu prodziekanowi dr. Andrzejowi Sosnowskiemu CR za opiekę podczas pobytu w Rzymie oraz za otrzymaną pomoc w związku z organizacją działań studenckich podczas okresu nauki.

Mamy nadzieję, że tradycja zostanie w przyszłym roku podtrzymana i kolejni studenci będą mogli uczestniczyć w równie ciekawych spotkaniach. 